\title{
Retaining Western Influence in Africa: The Ogaden War
}

While FPD officials were still finishing their report on Switzerland's Southern Africa policy that had been mandated after the Angolan War, tensions between the two socialist neighbours in the Horn of Africa were about to escalate. In an attempt to unite all ethnic Somalis in one state, the Somali army invaded the Ethiopian Ogaden region in July 1977, starting the only conventional war between two African states during the Cold War. The peasant liberation movements Western Somali Liberation Front (WSLF) and Somali-Abo Liberation Front (SALF), trained, armed, and commanded by the Somali state, had been fighting for more than a year in this desert area. By the time they were joined by regular Somali troops, the liberation movements were in control of most of the Ogaden region, except for the bigger towns. In July 1977, the Somali army quickly conquered the rest of the Ogaden lowlands before starting to attack the towns on the Harar plateau in mid-August. Fierce Ethiopian resistance soon brought the Somali offensive to a halt and stalemate began. ${ }^{1}$ The Good Offices Committee of the OAU, chaired by the Nigerian head of state, reaffirmed its central tenet of the inviolability of colonial borders and called for the respect of territorial sovereignty, thereby diplomatically backing Ethiopia's side in the conflict. Over the course of the following months, the OAU's repeated attempts to mediate a negotiated settlement failed. ${ }^{2}$

This conflict, between two of Africa's poorest states, would probably have raised little international interest, had it not been accompanied by a reversal of superpower alliances. In December 1976, the USSR and the Ethiopian PMAC had signed a military cooperation agreement. During a shootout in February 1977, Lieutenant Colonel Mengistu Haile Mariam eliminated his political rivals within the Ethiopian regime and was elected chairman of the Derg. Exasperated by the Somali invasion and its government's refusal to abandon its nationalist quest, the Soviet leadership increased military deliveries to Ethiopia in September 1977 and stopped providing Somalia with arms. In a desperate bid for Western support, the Somali head of state, Mohammad Siad Barre, abrogated the 1974 friendship treaty with the USSR on 13 November 1977, expelled

1 Gebru Tareke, "The Ethiopia-Domalia War of 1977 Revisited", pp. 638-651.

2 Amate, Inside the $O A U$, pp. $415^{-418}$ 
all Soviet experts from Somalia, and closed the Soviet bases in Berbera and Mogadishu. ${ }^{3}$

The Carter Administration, however, refused to grant overt, large-scale military aid to the aggressor for the duration of the Ogaden War. The conflict in the Horn of Africa was one of the Democratic administration's first foreign policy challenges. Jimmy Carter put a strong emphasis on human rights in foreign policy and called for a regionalist, long-term approach to Third World crises. He inherited a wait-and-see policy towards Ethiopia. Despite the Derg's antiAmerican rhetoric, the Ford administration had hoped to maintain its longstanding alliance with Ethiopia and had even increased military aid after the fall of Emperor Haile Selassie. ${ }^{4}$ The Derg's arms deal with the UssR, together with its human rights abuses, rendered this policy untenable to the Carter administration. The independence struggles in Ethiopia's peripheral regions, notably in Eritrea, were echoed by power struggles between competing Ethiopian Marxist-Leninist organisations and the Derg in the centre. Purges and assassinations began in mid-1976 and escalated after Mengistu's takeover in early 1977. It is estimated that about half a million Ethiopians lost their lives during the 'Red Terror' of 1977 and $1978 .{ }^{5}$

The growing US distance towards the PMAC in early 1977 was accompanied by a rapprochement with Somalia. The Saudi Arabian government, which was keen to entice Somalia, a fellow Muslim state, away from the Soviet Union, supported this. Somali leaders and their Arab allies pressed Western governments to provide alternative arms supplies if Somalia broke with the USSR. Rather than granting direct military aid to this regime, the Carter administration preferred to work through a Western consortium, an idea explored during talks with British, French, and West German diplomats. Siad Barre's well-known expansionist designs rendered arms deals problematic. This was particularly true for the UK and France, as the Somali government made claims to the territory of their allies Kenya, and Djibouti, whose independence from France was set for July 1977. Nevertheless, in June 1977, the UK, France, and the FRG agreed to provide

3 Westad, The Global Cold War, pp. 261-272; Yordanov, The Soviet Union and the Horn of Africa, pp. 138-162; 182-187.

4 Jackson,Jimmy Carter and the Horn of Africa, pp. 47-49; Woodroofe, 'Buried in the Sands of the Ogaden', pp. 47-49. Between 1974 and 1976, US military aid to Ethiopia amounted to an estimated \$197 million (CHF 492.3 million), more than half of all aid granted since 1953: Mitchell, Jimmy Carter in Africa, p. 178. The sum has been converted using the exchange rates for 1976 indicated in Officer, "Exchange Rates Between the United States Dollar and Forty-one Currencies".

5 Gebru Tareke, The Ethiopian Revolution, pp. 40-41; Andrew, Mitrokhin, The World Was Going Our Way, p. 457. 
small arms deliveries that were financed by Saudi Arabia. The so-called Safari Club also seems to have delivered some military aid to Mogadishu. This shadowy, informal intelligence alliance, created in the mid-1970s at France's behest as a result of the perceived weakness of the CIA, was aimed at containing Communism, mainly on the African continent. Its members included Saudi Arabia, Iran, Egypt, Morocco, and France. Somalia was also supported by Iran, Iraq, and other Middle Eastern and Northern African states. ${ }^{6}$

The Carter administration did not openly condemn the Somali invasion of July 1977, thereby following Mogadishu's line that its army was not fighting in the Ogaden. Since his open violation of the OAU principle of respecting the borders inherited from colonial times discredited his cause, Siad Barre insisted that the conflict in this region was a non-international fight for self-determination led by Ethiopian citizens. In early September, the US government publicly stated that US arms supplies to the Somali regime would not be forthcoming for the duration of the conflict. Behind the scenes, however, Washington encouraged its NATO allies and conservative Arab states to discreetly send arms to Somalia. ${ }^{7}$

After Siad Barre's break with the USSR in mid-November 1977, the Soviet leaders decided to massively back their remaining ally in the Horn of Africa. They increased deliveries of military equipment to Ethiopia via an air bridge and sent more than 1,0oo generals and military advisors to lead the Ethiopian defence. On 25 November 1977, Fidel Castro decided to accede to Ethiopian aid demands. Over the following months, up to 12,00o Cuban soldiers and 6,ooo advisors participated in a concerted operation under Soviet leadership to drive back the Somali invasion. According to Arne Westad, this was the "most important Soviet-led military operation outside the area of the Warsaw Pact since the Korean War". In early March 1978, Somali troops were forced to withdraw and the conventional war ended, although guerrilla resistance would continue for several years. ${ }^{8}$ A peace accord between Ethiopia and Somalia would only be signed in April 1988. ${ }^{9}$

The Ogaden War had few direct consequences for Switzerland's political and economic interests in the Horn of Africa. Swiss commercial exchanges with and

6 Mitchell, Jimmy Carter in Africa, pp. 191-194; 254-28o; on the Safari Club, pp. 172, 291-301.

7 Ibid., pp. 286-298.

8 Yordanov, The Soviet Union and the Horn of Africa, pp. 188-199; Westad, The Global Cold War, pp. $276-278$, citation p. 277 .

9 See Belete Belachew Yihun, "Ethiopian Foreign Policy and the Ogaden War: The Shift from 'Containment' to 'Destabilization', 1977-1991', Journal of Eastern African Studies 8:4 (2014), pp. 677-691; Flavia Gasbarri, "From the Sands of Ogaden to Black Hawk Down: The End of the Cold War in the Horn of Africa", Cold War History 18:1 (2018), pp. 73-89. 
investments in Somalia were almost non-existent and diplomatic relations had been de facto interrupted in 1975. Although Switzerland's political relations with the Derg had improved somewhat after the controversy surrounding the former Emperor's Swiss bank accounts died down, they remained distant. The Ethiopian government had a bad reputation in Bern. Apart from its nationalisation of Swiss interests and its Eastern bloc ties, the extensive human rights abuses of its 'Red Terror' also contributed to this. The internal conflicts in Ethiopia rendered the situation for foreigners so dangerous that ambassador Fritz Bohnert requested a hazard bonus for Swiss embassy personnel in March $1977 \cdot{ }^{10}$ The employees of private Swiss aid projects, missionaries, and business people left the country. By early August, shortly after the outbreak of the Ogaden War, only about ten Swiss citizens remained in Ethiopia. ${ }^{11}$

The Swiss government saw no need to deviate from a policy of non-interference, for several reasons; Switzerland had few interests in Ethiopia and Somalia, the stigma of its close economic and financial relations with South Africa was far less important than in Southern Africa, and Swiss non-state actors do not seem to have taken much notice of events in the Horn of Africa. Accordingly, its role during the Ogaden War was largely passive. Bern's decision-making during and after the Ogaden War was determined by Cold War considerations. Swiss foreign policymakers saw the Soviet-Cuban intervention in favour of the Ethiopian government as further proof of Soviet expansionism. In order to contribute to the containment of Soviet influence in Africa through Western efforts to provide African governments with an alternative to an alliance with the USSR, the Swiss authorities subsequently took some minor steps to deepen their relations with African states.

FPD leaders were not overly concerned about the outbreak of the Ogaden War. If anything, Federal Councillor Pierre Graber's opening speech at the annual

\footnotetext{
10 Telegram no 26 from Fritz Bohnert, Swiss ambassador in Ethiopia, to the FPD, 25.03.1977, SFA E2OO1E-o1\#1988/16\#3188*.

11 Letter from Fritz Bohnert to the DPA, "Ausländer in Aethiopien, Hilfe, Handelsvertreter", 29.04.1977, SFA E2001E-o1\#1988/16\#319o*; letter from Bohnert to the DIO and the stC, "Missionen, Rotes Kreuz, Terre des Hommes und Helvetas", 30.05.1977, SFA E2005A\#1991/16\#527*; letter from Bohnert to the DPA, "Jari: Helvetas und TdH. Diplomatischer Schutz ausländischer Hilfswerke", 31.07.1977, SFA E2005A\#1991/16\#520*; letter from Bohnert to the AD, "Addis Abeba: Diplomatische Missionen und ihre Aktionsmöglichkeiten", o8.08.1977, SFA E2Oo1E-o1\#1988/16\#3188*.
} 
conference of Swiss ambassadors in early September 1977 shows a certain satisfaction that "the USSR lost control of events" in the Horn of Africa and was "in a very delicate [...] situation". ${ }^{12}$ As he told the Council of States' Foreign Policy Committee a few days later, this "direct clash between two Soviet protégés" meant that the Soviet strategy to remain on good terms with both of its allies in the Horn of Africa was "close to complete failure". Graber concluded: "there seems to be no imminent danger of a relapse into the Cold War."13 Following Somalia's break with the USSR on 13 November 1977, the FPD's Political Secretariat considered the USSR's loss of one of its most important allies in subSaharan Africa to be of more interest than the outcome of the war. ${ }^{14}$ The Swiss government's role during the Ogaden War was very low-key. It adopted a position of impartiality and granted financial support to the ICRC relief mission, as it had done during the Angolan War. However, Ambassador Fritz Bohnert's reports from Addis Ababa reveal a certain pro-Somali bias. In mid-October, he still talked of civil war in the Ogaden rather than international conflict between Ethiopia and Somalia, thereby backing Mogadishu's line. ${ }^{15}$

Somalia's rapprochement with the Western bloc led to the re-establishment of diplomatic relations between Mogadishu and Bern. As a result of the Somali government's cavalier treatment of the Swiss ambassador to Tanzania, the FPD had, in early 1975, decided not to accredit another ambassador to Somalia. In April 1977, since it appeared likely that Siad Barre's government would turn away from the USSR, the Swiss authorities reconsidered. The Somali regime reacted positively to the Swiss suggestion of renewing diplomatic relations, probably out of a general willingness to diversify its foreign relations and convince more powerful potential Western donors of Somalia's readiness for a change in alliances. ${ }^{16}$ The practical advantages of a diplomatic representa-

12 Opening speech held by Pierre Graber, Federal Councillor and head of the FPD, on 1 September 1977, "exposé liminaire", pp. 10-11, appendix no 5 of the minutes of the Annual Conference of Swiss Ambassadors 1977, SFA E2010-01A\#1990/5\#10*.

Pierre Graber's speech at the meeting of the Foreign Policy Committee of the Council of States on 8 September 1977, "Tour d'horizon", no date, pp. 2O-21, SFA E1050.12\#1995/512\#11*. Note from Jean Cuendet, head of the Political Secretariat of the FPD, to the head of the FPD, "Corne de l'Afrique: le ton monte à Mogadiscio", 14.11.1977, SFA E2010-01A\#1990/5\#201*. PR no 21 by Fritz Bohnert, "Aethiopien vor dem Verlust der Hälfte seines Gebietes, gute Dienste der OAU”, 08.08.1977, SFA E2300-01\#1988/91\#100*; letter from Bohnert to the DIO, "Aethiopien: Hilfsgesuche", 17.10.1977, SFA E2001E-o1\#1991/17_Bd. 759, B.55.40.

16 Telegram no 68 from Hansjakob Kaufmann, deputy chief of the DPA's African, Asian, Middle Eastern and Latin American Division, to the Swiss embassy in Kenya, 20.04.1977, SFA E2001E-o1\#1991/17_Bd. 1096, B.15.21; note from Alfred Glesti, AD, to the DPA, "Somalie", 20.05.1977, SFA E2004B\#199o/219\#381*; letter from Hans Miesch, Swiss ambassador 
tion for the protection of Swiss citizens are insufficient to explain the Swiss government's change of mind. It was, however, consistent with the principle of the universality of diplomatic relations, an integral part of Switzerland's conception of neutrality since the Second World War. Nevertheless, between 1975 and early 1977, concern about neutrality had not prevented the Swiss government from infringing the principle of universality in the case of Somalia, a state with little political and economic importance for Switzerland whose government was allied to the USSR and had been less than friendly towards the Swiss ambassador. It was the possibility that the war with Ethiopia might motivate Somalia to turn towards the West that spurred Swiss efforts to normalise relations with this state. In late October 1977, the FPD renewed contact with the Somali government, which had been temporarily halted in July. As a result, the Federal Council decided, in February 1978, to nominate the Swiss ambassador to Tanzania to represent Switzerland in Somalia. ${ }^{17}$ The re-establishment of diplomatic relations with Somalia can thus be interpreted as a low-cost and low-risk means of contributing to efforts to wean the Somali government off the USSR and to contain Communism in the Horn of Africa.

During and after the Ogaden War, Ambassador Fritz Bohnert repeatedly underlined that there was no opportunity to offer Switzerland's good offices, as Africans preferred to resolve their own disputes. ${ }^{18}$ Even if the OAU had not claimed the role of mediator, the fact that the Swiss government did not have diplomatic relations with both belligerents through most of the conflict made it an unlikely candidate to play an active role. There was no opportunity to act as an intermediary to the superpowers, either. In a telegram to the State Department in December 1977, the US Chief of Mission in Addis Ababa excluded the possibility of entrusting Bern with the protection of American interests in the case of a rupture between the US and Ethiopia. According to him, not only was the staff of the Swiss embassy in Addis Ababa too small but Bohnert's personality was also unsuited to handling such a task: "present ambassador is frightened for his own safety (having evacuated family) and shows no natu-

in Kenya, to the DPA, "Akkreditierung eines schweizerischen Botschafters in Somalia", 17.05.1977, SFA E2004B\#1990/219\#381*.

17 Letter from Hans Miesch to the AD, "Relations diplomatiques avec la Somalie", 15.09.1977, SFA E2OO4B\#199O/219\#381*; telegram no 92 from Alfred Glesti to the Swiss embassy in the FRG, 31.10.1977, ibid.; letter from Glesti to Michael Gelzer, Swiss ambassador in the FRG, secret, 14.02.1978, ibid.

18 Telegram no 124 from Fritz Bohnert to the FPD, 30.09.1977, SFA E2001E-o1\#1988/16\#3190*; letter from Bohnert to the DPA, "Aethiopien: Vermittlung und Gute Dienste", confidential, 16.o3.1978, ibid. 
ral rapport with Ethiopians. If ambassador had choice, he would close Swiss embassy entirely."19

While the Swiss government had neither the will nor the opportunity to play a political role during the Ogaden War, the field of humanitarian aid provided possibilities for action, notably through the intermediary of the ICRC. In mid1977, the ICRC launched a relief mission to aid the victims of the conflict in the Ogaden. The Swiss government supported this mission, yet its role was more discreet than in Angola. The two belligerents' different views on the nature of the war-an international armed conflict where international humanitarian law applied (Ethiopia) vs insurgents fighting for self-determination (Somalia)-hampered the ICRC's activities. The PMAC even called the ICRC's neutrality into question, because the Geneva-based organisation accepted the Somali government's refusal to consider itself a party to the conflict. Thus, there was a risk that Switzerland's neutrality might suffer due to its association with the ICRC. ${ }^{20}$

In early August 1977, a few weeks after the outbreak of the Ogaden War, the ICRC sent emergency aid to the Horn of Africa. The organisation made an appeal to the conflicting parties as well as the OAU, calling for international humanitarian law in armed conflicts to be respected. The DPA approved of the ICRC's activities. Its deputy director Jürg Iselin sent diplomatic reports from the Swiss embassies in Ethiopia and the US to his former colleague as Ambassador to Kenya, Richard Pestalozzi, who had joined the ICRC in $1976 .{ }^{21}$ The ICRC also sent delegates to Addis Ababa and Mogadishu in order to offer its services. The Ethiopian PMAC consented to let the ICRC visit prisoners of war and organise relief for civilians. The Somali government, however, refused to be considered a party to an international conflict and declined to discuss the application of the Geneva Conventions. Nevertheless, it authorised the ICRC to collaborate with the Somali Red Crescent Society to aid refugees. The ICRC also managed to establish contacts with the WSLF fighting in the Ogaden. This gave rise to considerable diplomatic tension between the ICRC and the Derg

19 Telegram by Richard Matheron, Chief of Mission of the US embassy in Ethiopia, to the Secretary of State, 23.12.1977, NARA, RG 59, AAD, CFPF, Electronic Telegrams 1977, 1977 ADDISo70o6.

20 The analysis of Switzerland's humanitarian role during the Ogaden War is subject to a double bias. As the ICRC archives have not yet released any documents dated after 1975, the study relies on the organisation's published annual reports and SFA documents. In addition, the information in the latter is decidedly one-sided, as the FPD had no direct source of intelligence in Somalia.

21

Letter from Jürg Andreas Iselin, deputy chief of DPA and chief of its African, Asian, Middle Eastern and Latin American Division, to Richard Pestalozzi, ICRC, 04.08.1977, SFA E2001E-ol\#1988/16\#319\%*. 
and hampered the former's mission for several months. In its official appeal for donations to its relief effort on 8 September, the ICRC mentioned having been in contact with the WSLF and did not name the Somali government as aggressor. Ethiopian officials and the Soviet ambassador in Addis Ababa strongly criticised this. ${ }^{22}$

While the ICRC attempted to resolve its difficulties with the Derg, the Swiss authorities had to decide on whether to participate in a UNDP project to provide trucks for the Ethiopian government, mainly to be used for emergency aid in famine areas and agricultural projects. Ambassador Bohnert and the STC agreed that the risk that these trucks might be repurposed for military use was too great. This would have undermined the credibility of Switzerland's policy of neutrality if not balanced with aid to the other warring party. Therefore, it was decided to channel Swiss aid through the ICRC. ${ }^{23}$ The decision not to contribute to the UNDP project was judicious. After the end of the Ogaden War, it transpired that the Ethiopian authorities had frequently used vehicles donated for humanitarian purposes for military ends. ${ }^{24}$

In January 1978, the ICRC achieved a breakthrough. After talks with an ICRC representative, the PMAC authorised the resumption of aid distributions that had stalled for months. This was to be done "jointly and in consultation with the Ethiopian Red Cross Society."25 The limited cooperation from the Ethiopian and Somali governments left the ICRC unable to fully develop its

22 Letter from Fritz Bohnert to the DIO and the DPA, "IKRK-Aktion in Aethiopien", 03.10.1977, SFA E2001E-o1\#1988/16\#319o*. See also Jean-Pierre Hocké, Director of the ICRC's Operations Department, copy of the ICRC's appeal to main donors on 8 September 1977, 09.09.1977, "International Committee of the Red Cross Appeal for Victims of Ogaden Conflict", attached to the letter from Fritz Bohnert to the DPA, "Das IKRK in Aethiopien, August 1977-Juli 1978”, 17.07.1978, SFA E2003A\#1990/3\#679*; ICRC, Annual Report 1977, Geneva: ICRC, 1978, pp. 13-14.

23 Letter from Fritz Bohnert to the DIO, "Aethiopien: Hilfsgesuche", 17.10.1977, SFA E20o1E-o1\#1991/17_Bd. 759, B.55.40; letter from Bohnert to the sTC, "Hilfe für Aethiopien: Aufruf für Nottransport-Flotte von 125 Lastwagen”, 12.12.1977, SFA E2005A\#1991/16\#520*; letter from Rudolf Dannecker, head of the sTc's Eastern Africa Section, to the Swiss embassy in Ethiopia, "Hilfe für Aethiopien: Aufruf für Nottransport-Flotte von 125 Lastwagen”, 13.01.1978, SFA E2005A\#1991/16\#521*.

24 Letter from Fritz Bohnert to the Trade Division, the STC, and the DPA, "Wirtschaftsbeziehungen mit und Hilfe an Aethiopien. Besuch Cheysson EG. Besprechung mit Planungschef und MFA“, 12.06.1978, p. 6, SFA E2005A\#1991/16\#521*.

25 Letter from Teferra Wonde, Ethiopian Minister of Health, to Eddi P. Leemann, head of the ICRC mission in Ethiopia, 06.02.1978, attached to the letter from Fritz Bohnert to the DPA, "Das IKRK in Aethiopien, August 1977-Juli 1978", 17.07.1978, SFA E2003A\#199o/3\#679*; see also the letter from Bohnert to the STC, "IKRK: Mission Prof. Fleiner in Addis Abeba", 30.01.1978, SFA E2OO1E-o1\#1988/16\#319o*. 
activities. Its delegates in the two states focused mainly on the distribution of relief goods to refugees. For this, the organisation received donations in cash and kind amounting to CHF 4.1 million by the end of the war in late March 1978. After the end of hostilities, the ICRC supported medical projects in both Ethiopia and Somalia and continued the distribution of relief goods for some months, until UN specialised agencies took over. ${ }^{26}$ The Swiss government's exact contribution to the ICRC relief mission in the Ogaden is not known. In 1977, its total humanitarian aid to Ethiopia and Somalia, distributed by different national and international charities, amounted to CHF 2 million and CHF 0.5 million, respectively, which was $2.6 \%$ and $0.6 \%$ of Switzerland's overall budget for humanitarian aid. The contributions were lower in the following year, amounting to CHF 315,000 (Ethiopia) and CHF 370,00o (Somalia) up to October $1978 .{ }^{27}$ In Ethiopia, a part of this contribution probably went to other conflict zones, notably Eritrea.

In a long letter to the FPD four months after the end of the Ogaden War, Ambassador Fritz Bohnert strongly criticised the ICRC's role during the conflict. His list of the organisation's blunders was long: insufficient examination of the wording of the international appeal for aid; bad handling of the Ethiopian complaints; and a lack of insistence on respect of the Geneva Conventions. The biggest problem was the ICRC's collaboration with the Ethiopian Red Cross, which was, according to Bohnert, in the full control of the Derg; since the two organisations shared offices in Addis Ababa, Bohnert claimed that the ICRC delegates' work was controlled by the Ethiopian organisation, which had access to ICRC records. Furthermore, the delegation from Geneva received few travel permits and was thus unable to control the distribution of relief funds. For the ambassador, the ICRC's dependence on a body controlled by a totalitarian government threatened the credibility of the Geneva organisation. This was even more galling as "any activity of the ICRC is seen by the relevant parties here as 'Swiss' and as an expression of our neutrality." 28

26 Telegram from [?] Santschy, ICRC, to delegate [?] Jäckli in Ethiopia, 31.03.1978, attached to the letter from Fritz Bohnert to the DPA, "Das IKRK in Aethiopien, August 1977-Juli 1978", 17.07.1978, SFA E2003A\#199o/3\#679*; ICRC, Annual Report 1978, Geneva: ICRC, 1979, pp. 18-19. Letterfrom ArthurBill, theFederal Council's Delegate for Disaster Relief Abroad, to theSwiss embassy in Ethiopia, "Ethiopie: demande d'aide", o2.11.1977, SFA E2005A\#1991/16\#520*; letter from Alfred Rüegg, DPA, to the Swiss Permanent Mission in Geneva, "Athiopischschweizerische Freundschaftsgesellschaft", o8.02.1979, SFA E2001E-o1\#1991/17_Bd. 759, B.38.21.Eth.1.; telegram no 129 from Hansjakob Kaufmann to the Swiss embassy in Tanzania, 09.10.1978, SFA E2001E-o1\#1991/17_Bd. 1096, B.15.21; Swiss Federal Council, Bericht des Bundesrates über seine Geschäftsführung im Jahre 1977, 06.03.1978, p. 29. 
Nevertheless, Switzerland's role as host country of the ICRC, one of Ethiopia's main potential future aid donors, was probably behind the dubious honour conferred on Bohnert of being the only neutral and Western European participant in a propaganda visit to the Ogaden organised by the Ethiopian foreign ministry in April 1978. The visit to the war zone had two main goals: first, to convince foreign observers of Somali brutality in order to counter allegations that the Ethiopian troops were committing genocide against the Somali population of the Ogaden; second, to strengthen Ethiopian demands for international humanitarian aid in order to repair the war damages. It was arranged for about thirty selected representatives of international organisations and diplomats, mainly from African and Third World states, but also Eastern European countries. As the Western press was highly critical of Ethiopia, only the Swiss and the Dutch ambassadors were invited. The invitation to the latter was subsequently withdrawn, however, as he did not immediately confirm. Although the Swedish government had just granted aid to Ethiopia amounting to CHF 70 million, its ambassador was not welcome on the tour. The propaganda visit did not have the desired impact on the Swiss government. It confirmed Bohnert's conviction in the Ethiopian regime's brutality and failed to stimulate substantial Swiss humanitarian assistance. ${ }^{29}$

After the end of hostilities in the Ogaden, Switzerland's foreign policy in the Horn of Africa remained low-key. Swiss economic interests in Ethiopia and Somalia were negligible and neither government was deemed politically stable or reliable enough to launch long-term development cooperation projects. ${ }^{30}$ Nevertheless, the Swiss government continued to grant limited humanitarian aid. According to Fritz Bohnert, this would help maintain a minimal Swiss political presence in Ethiopia, which he considered advisable in order to react to possible export opportunities. ${ }^{31}$

29 Fritz Bohnert, report, "Besuch im Ogaden in einer diplomatischen fact-finding mission, 5.-6- April 1978”, 10.04.1978, p. 1, SFA E2OO1E-01\#1988/16\#319o*. See also telegram by Richard Matheron to the Secretary of State, 11.04.1978, NARA, RG 59, AAD, CFPF, Electronic Telegrams 1978, 1978ADDISo1659.

30 See the letter from Rolf Wilhelm, Vice-Director of the STC, to the Swiss embassy in Ethiopia, "Aethiopien Finanzhilfe", 24.01.1979, SFA E2025A\#1991/168\#652*; No author (STC), memorandum, "deux possibilités", 07.03.1979, and the attached memorandum by CA [?], 22.01.1979, SFA E2O25A\#1991/168\#1648*.

$31 \quad$ Fritz Bohnert, report, "Besuch im Ogaden in einer diplomatischen fact-finding mission, 5-6- April 1978", 10.04.1978, p. 1, SFA E2001E-o1\#1988/16\#319o*; letter from Bohnert to the Trade Division, the STC, and the DPA, "Wirtschaftsbeziehungen mit und Hilfe an Aethiopien. Besuch Cheysson EG. Besprechung mit Planungschef und MFA", 12.06.1978, SFA E2005A\#1991/16\# $521^{*}$. The sums indicated in US\$ have been converted to CHF using the exchange rates for 1976 and 1978 indicated in Officer, "Exchange Rates Between the United States Dollar and Forty-one Currencies". 


\section{"Sources of Infection": Contributions to the Containment of Soviet Power in Sub-Saharan Africa}

For Swiss foreign policymakers, the Ogaden War mattered mainly because of its implications for global East-West relations. Ever since the arrival of Cuban troops on Angolan soil in November 1975, growing Soviet influence in Africa had been a source of worry. A number of crises in 1977 and 1978 heightened this sense of a Soviet menace on the continent. After the first invasion of the Shaba province in Zaire by the Angola-based Katangese gendarmes in early 1977, the large-scale Soviet - Cuban intervention during the Ogaden War, which was swiftly followed by the second Shaba crisis in May 1978, was seen as a further, huge advance in Soviet plans to dominate Africa. In mid-March 1977, as tensions in the Horn of Africa increased and the Katangese gendarmes invaded the Shaba province, the head of the Political Secretariat, Jean Cuendet, addressed a note on the "African crisis" to Federal Councillor Pierre Graber. This crisis consisted in a growing number of armed conflicts fuelled by the Soviet Union, which might spread out from the four main "sources of infection": Southern Africa, the Horn, Shaba, and Western Sahara. ${ }^{32}$ Dismissing the strategic benefits of the UssR's presence in Angola, Mozambique, and Somalia, the author struggled to understand the aims of Moscow's strategy on the continent. Its policy seemed, to him, motivated by a vague desire to "create trouble for the West" and to get retribution for setbacks that the USSR had suffered elsewhere on the globe. Washington's role in Africa did not fill Cuendet with optimism. He saw no fundamental difference in the arrival of Jimmy Carter in the White House: "The United States still do not have an Africa policy. They are just more receptive to the Africans' complaints". ${ }^{33}$

Pierre Graber's May 1977 tour d'horizon speech to the parliamentary Foreign Policy Committees presented the Shaba crisis and the UssR's growing influence in Ethiopia as a clear escalation in the new era of great power competition for Africa, which had started after the Cuban invasion in Angola. As the US seemed unable to counter these advances and the OAU appeared completely paralysed, the politically and economically weak African continent appeared to be at the UssR's mercy. The French government's willingness to step into the breach was seen as a rare ray of hope. Graber seems to have welcomed the French airlift of Moroccan troops to Zaire, which ended the first invasion of Shaba. According to him, this dispelled the danger of Zaire, and other moderate African states,

\footnotetext{
32 Note from Jean Cuendet to Pierre Graber, "La crise africaine", 21.03.1977, p. 1, SFA E2010o1\#1990/5\#197*.

33 Ibid., p. 3 .
} 
falling to the Soviet Union. ${ }^{34}$ This image of passive African governments and a powerless OAU contrasts markedly with the importance that FPD leaders had ascribed to these actors when it came to Switzerland's relations with the white minority regimes in Southern Africa, most importantly concerning Swiss recognition of the PRA. While African states had the means to cause embarrassment for Switzerland on the matters of image and economic interests on the continent, they were not judged powerful enough to significantly influence the East-West struggle-or even to resolve their own problems. The tour d'horizon also provided an explanation of Soviet aims in Africa: "Unfortunately, one has to fear that the first objective of this policy currently consists in harming the West and cutting it off from its economic positions in Africa." ${ }^{35}$ Graber argued that, according to the Kremlin, Western imperialism relied on the neocolonial exploitation of this continent. He therefore concluded that the USSR intended to separate its enemies from the roots of their power. Although this perceived attack on Western economic interests extended to Switzerland, Swiss foreign policymakers did not deem it urgent enough to warrant action. This would change after the Soviet-Cuban intervention in the Ogaden.

FPD leaders initially saw the Ogaden War between two Soviet allies as a setback for the USSR. In late 1977, rather than focusing on the Horn, their attention was on Southern Africa - a region where their interests were far more substantial. In addition, US, British, and African pressure would shortly result in the introduction of a Swiss regulation to prohibit trade and financial transactions with Rhodesia. ${ }^{36}$ The Soviet-Cuban intervention in support of the PMAC as 1977 turned to 1978, however, caused much consternation in Bern. It reinforced worries about the US government's seeming inability to counter the USSR's advances in Africa and raised the fear that other African actors might attempt to achieve their political goals by calling on Soviet military power. ${ }^{37}$

34 Pierre Graber's speech at the meetings of the Foreign Policy Committees of the National Council on 24 May 1977 and of the Council of States on 25 May 1977, "Tour d'horizon", no date, pp. 24-32, SFA E1050.12\#1995/512\#11*.

35 Ibid., p. 29.

36 See Opening speech held by Pierre Graber on 1 September 1977, "exposé liminaire", pp. 6-11, appendix no 5 of the minutes of the Annual Conference of Swiss Ambassadors 1977, SFA E2010-o1A\#1990/5\#10*. On the Carter administration's efforts to end white minority rule in Rhodesia, see Andrew J. Deroche, "Standing Firm for Principles: Jimmy Carter and Zimbabwe", Diplomatic History 23:4 (1999), pp. 657-685; Mitchell, Jimmy Carter in Africa; Sue Onslow, "South Africa and the Owen/Vance Plan of 1977", South African Historical Journal 51 (2004), pp. 130-158.

37 See notably PR no 7 by Fritz Bohnert, "Aethiopien: Erfolg des neuen sowjetischen Interventionsmodells und Folgen für Afrika", 13.03.1978, p. 3, SFA E230o-o1\#1988/91\#196*. 
The new head of the FPD dedicated most of his May 1978 tour d'horizon speech to the Horn of Africa. In early 1978, the newly elected Federal Councillor Pierre Aubert had taken over from his fellow Social-Democrat, Pierre Graber, who stepped down after having led the department for eight years. Aubert continued and sought to intensify the active foreign policy of his predecessors. With a stronger emphasis on human rights and development cooperation with the Third World, he aimed to render Switzerland's foreign policy more dynamic and move beyond a position beholden to a conception of neutrality based on non-interference. ${ }^{38}$ In his speech to the foreign policy specialists, Aubert underlined that Soviet policy in Africa "is at odds with the spirit, at least, of Détente" and caused considerable embarrassment to the US. Since in the wake of the Vietnam War, it would be unthinkable to commit American troops, the Carter administration was compelled to adopt a policy of abstention. This damaged its credibility in Africa. At the same time, the Federal Councillor was convinced that Africa had no intrinsic importance for the USSR: "In the eyes of the Soviet Union, Africa is mainly a source of raw materials for the West."39 At the meeting of the Council of States' Foreign Policy Committee on 19 May 1978, the day that the first French troops landed in the Zairean city of Kolwezi to liberate European expatriates taken hostage during the second invasion of Shaba, the conservative committee members worried that the US underestimated the Soviet danger in Africa. While the FPD leaders present attempted to restore the committee's confidence in the Western superpower, Jean Cuendet voiced the department's main fear; that "certain African states, whose mining and agricultural production is crucial for Europe and the United States, might fall into the hands of regimes that are hostile to them". 40 The potential danger to their economic interests in Africa, which seemed more critical after the Ogaden War, spurred FPD leaders into action.

In the middle of 1978, FPD leaders frequently raised the issue of the Soviet penetration of Africa in bilateral meetings with Western and international

38 On Federal Councillor Pierre Aubert's conception of Swiss foreign policy and the conflicts this generated within the FPD, most prominently with Secretary-General Albert Weitnauer, adherent of a foreign policy strictly based on a selective understanding of neutrality, see Fischer, Die Grenzen der Neutralität, pp. 268-285. Fischer argues that their different conceptions of Switzerland's international role played a major part in the conflict that led to Weitnauer's early retirement in early 1980. States on 19 May 1978, "Tour d'horizon", no date, p. 28, SFA E1050.12\#1995/512\#12*.

40 Statement by Jean Cuendet, minutes of the meeting of the Council of States' Foreign Policy Committee on 19 May 1978, no date, p. 12, SFA E1050.12\#1995/512\#12*. 
leaders and diplomats. ${ }^{41}$ During a lunch meeting with the US ambassador in Bern in late June 1978, Pierre Aubert applauded Jimmy Carter's speech of 7 June at the US Naval Academy in Annapolis. In this speech, the President had criticised the Soviet intervention by proxy in the Ethiopian conflict and called on the USSR to choose between confrontation or cooperation with the US. Aubert expressed Switzerland's and Western Europe's relief at the firm American response to Soviet moves in Africa. In a telegram to the Department of State, Ambassador Marvin Leon Warner pointed out that Aubert had repeatedly insisted on the "importance of US strength for independence of weaker nations" - the Federal Councillor even referred to the US as "big St Bernard".42 Whether or not Aubert included Switzerland in the ranks of states needful of US protection, his reference to the Catholic saint - and founder of travel shelters in the Alps - can be read as an appeal to the US to assume its leadership role in a harsh international climate. FPD leaders wished for a more forceful US role on the African continent. Although they did not go as far as to claim that Détente was "buried in the sands of the Ogaden", as US National Security Advisor Zbigniew Brzezinski did in his memoirs, ${ }^{43}$ they were of the opinion that the events in the Horn of Africa undermined Détente—and that the USSR was responsible for this.

After the Ogaden War, Swiss foreign policymakers started to think about what the West-and Switzerland-might do to prevent further opportunities for Soviet interventions. The UssR's growing influence in Africa prompted intelligence bodies within the Swiss federal administration to embark on a detailed analysis of the continent's role in the Cold War, Western states' possibilities to influence the situation to their advantage, and Switzerland's role in this context. In a widely circulated report, Erwin Hofer of the Political Secretariat insisted in September 1978 that Africans had no deep-rooted attachment to socialism. They only turned to the USSR if they were unable to find other

See notably Sylvie Michl-Keller, Political Secretariat, speaking notes, "Visite à Rome 10/11 juillet. Corne de l'Afrique", 29.06.1978, SFA E2O1O-o1A\#19o/5\#2O2*; KR, Michl-Keller, Hansjörg Renk, Political Secretariat, "Visite Waldheim 6/7 juillet. Afrique", 05.07.1978, SFA E2010-01A\#19o/5\#197*.

Telegram by Marvin Leon Warner, US ambassador in Switzerland, to the Secretary of State, 29.06.1978, NARA, RG 59, AAD, CFPF, Electronic Telegrams 1978, 1978BERNo3125; see also US President Jimmy Carter's address at the commencement exercises at the United States Naval Academy on 7 June 1978, in Gerhard Peters, John T. Woolley, The American Presidency Project, https://www.presidency.ucsb.edu/documents/address-thecommencement-exercises-the-united-states-naval-academy (13 January 2021). A detailed analysis of this speech can be found in Mitchell, Jimmy Carter in Africa, pp. 440-442.

Cited in Westad, The Global Cold War, p. 282. 
allies to attain their goals. Consequently, once Soviet and African interests were no longer aligned, new alliances would become possible. As things stood, Western and African governments were on opposite sides with regard to the latter's two major international goals: the decolonisation of Southern Africa and the redistribution of economic wealth to the global South. Nevertheless, the author concluded that the African continent remained mostly tied to the West. This was explained, in a simplistic and patronising way, by the Africans' attachment to Western values and religion and the fact that the continent's economic development depended mainly on Western states. ${ }^{44}$ Although this report did ascribe African actors a certain room for manoeuvre in their choice of alliances, Hofer still portrayed them as largely passive and easily influenced by one side or the other.

This view was also taken up by the Security Conference, a coordination unit within the FMD responsible for the exchange of strategic and security policy information among the federal administration's different departments. Its head decided in October 1978 to dedicate one of its monthly meetings to Africa. ${ }^{45}$ A report of more than forty pages, written by Erwin Hofer, which summarised contributions by the FPD, the Trade Division, and the FMD, served as a basis for the discussion, held in early December. As the meeting's minutes have not been declassified, this report provides fascinating insights into Swiss policymakers' perception of the threat to Swiss interests and their strategies to counter them. With regard to Africa's role in global East-West relations, it argued that, as Western "intellectual, cultural, and economic resources" were superior and the USSR and Cuba had only been able to gain a foothold in Africa during conflicts, Western states needed to prevent and limit local and international crises. Also, they should deepen their ties with African governments. ${ }^{46}$

44 Erwin Hofer, Political Secretariat, memorandum, "Afrika als eigenständiger Faktor der internationalen Politik. Eine Analyse bisheriger Entwicklungen und möglicher Zukunftsaussichten", confidential, 28.09.1978, SFA E2O1O-O1A\#19o/5\#197*.

45 Letter from Richard Ochsner, FMD, chairman of the Conference, to Jean Cuendet and Fritz Rothenbühler, Trade Division, "Westlicher Einfluss und spezifisch schweizerische Interessen in Afrika", 19.10.1978, attached to the note from Cuendet to the STC, DPA, Financial and Economic Service of the FPD, Service for Consular Protection, "Lagekonferenz: Westlicher Einfluss und schweizerische Interessen in Afrika”, 25.10.1978, confidential, SFA E2005A\#1991/16\#543*.

46 Erwin Hofer, report, "Die Möglichkeiten der westlichen Präsenz und die schweizerischen Interessen in Afrika", 22.12.1978, pp. 3-4, citation p. 4, attached to the letter from Richard Ochsner to the people invited to the Conference, and from Jean Cuendet to all FPD section heads, the leaders of the Trade Division, and selected Swiss embassies, "Die Möglichkeiten der westlichen Präsenz und die schweizerischen Interessen in Afrika", 22.12.1978, SFA E2O10-O1A\#19o/5\#197*. 
Despite Switzerland's policy of neutrality, the country was considered part of the West. Consequently, Swiss foreign policymakers felt the need to participate in efforts to contain Soviet advances.

According to the report, Switzerland had not exhausted the limited means of a small state to help retain the allegiance of African states to the West. In particular, it could increase economic and development cooperation and strengthen its political, cultural, and scientific dialogue with Africa. ${ }^{47}$ With regard to bilateral relations, the biggest potential threat to Swiss interests on the continent was identified as Southern Africa. On the one hand, armed conflicts in this region might cut trade and financial relations, destroy investments, and endanger Swiss citizens in South Africa and Rhodesia. On the other hand, a Swiss refusal to apply sanctions against South Africa might endanger its economic interests in other African states. ${ }^{48}$ The few actions proposed to protect Swiss interests reveal a certain helplessness, as Switzerland's political, economic, and financial relations with South Africa again limited its government's policy options. While a credible policy of neutrality was judged useful, the author had to admit that the Swiss government's verbal condemnation of Apartheid alongside Swiss economic and financial circles' support for South Africa did raise "occasional doubts" about Switzerland's neutrality in Africa. While economic measures were considered to be of limited use, active participation in the North-South dialogue might indirectly protect Swiss interests. ${ }^{49}$ The report had no new strategies to offer, and only suggested reinforcing policy instruments that were already in use: economic and development aid as well as political dialogue with African leaders. Pierre Aubert's January 1979 trip to Western Africa was an occasion to put these conclusions into practice.

\section{A Federal Councillor's Africa Trip, or the Limits of a More Active Foreign Policy}

The initiative for Federal Councillor Pierre Aubert's 1979 Africa trip went back to mid-1978. After the Soviet-Cuban intervention in the Ogaden, FPD leaders started to think about how Switzerland might help prevent further opportunities for Soviet intervention in Africa. Although it is not quite clear when and in what context the idea originated, by mid-July 1978 Aubert had decided to go on a goodwill mission to Western Africa. He seems to have insisted on

\footnotetext{
47 Ibid., pp. 8-9.

48 Ibid., pp. 20-22.

49 Ibid., pp. 23-25, citation p. 23.
} 
this trip even though his staff considered that his travel programme in 1979 was already overloaded. The Federal Councillor's original goals were to foster goodwill towards Switzerland, exchange ideas on key issues of world politics, and resolve bilateral issues. ${ }^{50}$ Aubert's two-week trip to Nigeria, Senegal, the Ivory Coast, Cameroon, and Burkina Faso in January 1979 has been described as extraordinary and novel, both for its geographical focus and scope. ${ }^{51}$ It was uncommon for members of Switzerland's collective government go on a state visit. Aubert's insistence on Africa testifies to the importance he ascribed to the continent in the East-West confrontation and to the perceived need to reinforce Switzerland's bilateral relations with African states. Yet, the domestic controversy caused by his trip illustrates the limits on a more active Swiss foreign policy in the late 1970s.

For the Federal Councillor's visit, the FPD chose African states that were "close to our own", meaning they were states with which Switzerland had important economic links or particularly cordial political relations, or where it supported development cooperation projects. ${ }^{52}$ This limited the political risks of the trip. As "Africa's leading nation", Nigeria was selected for its political importance. ${ }^{53}$ It had chaired the OAU's Good Offices Committee during the Ogaden War. The fact that Nigeria had been, in 1977, Switzerland's main trade partner on the African continent, surpassing even South Africa, certainly did not hurt, either. ${ }^{54}$ Switzerland's political links with the Ivory Coast and Senegal were qualified as very cordial, while economic relations were characterised as

50 Note from Jürg Andreas Iselin to Marcel Heimo, Delegate for Technical Cooperation, and Jimmy Martin, head of the AD, 14.07.1978, SFA E2Oo1E-o1\#1988/16\#499*; Rudolf Emil Stauch, DPA, memorandum of conversation "Westafrikareise des Departementchefs", ol.og.1978, ibid.

Urban Kaufmann, Auslandreisen der Schweizer Bundesräte 1919-1993. Die Gewöhnung an das Aussergewöhnliche, unpublished Master thesis, University of Fribourg, 1996, pp. 83-84. No author, FPD, report, "Premier bilan du voyage du Chef du Département politique au Nigéria, au Cameroun, en Haute-Volta, en Côte d'Ivoire et au Sénégal (14 au 28 janvier 1979)", 30.01.1979, pp. 1-2, citation p. 2, SFA E2001E-o1\#1991/17_Bd. 106, B.15.22.3.

53 Rudolf Emil Stauch, memorandum of conversation "Westafrikareise des Departementchefs", o1.09.1978, p. 2, SFA E2001E-o1\#1988/16\#499*. See also the note from Jürg Andreas Iselin to Marcel Heimo and Jimmy Martin, 14.07.1978, ibid.

54 In 1977, Swiss imports from Nigeria amounted to CHF 193.1 million, 19.7\% of all Swiss imports from Africa, and $0.4 \%$ of total Swiss imports, followed by South Africa (CHF 127 million) and Algeria (CHF 125 million). Swiss exports to Nigeria amounted to CHF 391 million (17.4\% of Swiss exports to Africa and 0.9 worldwide), compared to 350 million (South Africa) and 336 million (Algeria): Erwin Hofer, Political Secretariat, report, "Die Möglichkeiten der westlichen Präsenz und die schweizerischen Interessen in Afrika", 22.12.1978, p. 36, attached to the letter from Richard Ochsner to the people invited to the Conference, and from Jean Cuendet to all FPD section heads, the leaders of the Trade 
substantial. Cameroon and Burkina Faso were chosen as examples of "typical poor developing countr[ies]".55

Although bilateral economic interests played a role in the selection of states to visit, economic motives were not a priority for Aubert's trip. They seem to have been added to the agenda to 'sugar the pill' and make the trip palatable to a Swiss public highly critical of 'travelling diplomacy'. The Federal Councillor embarked on his tour to foster goodwill in Africa towards Switzerland and to discuss the continent's role as an arena of the global Cold War with African leaders. According to the speaking notes prepared for Aubert in December 1978 , he wished to encourage the peaceful settlement of local and regional conflicts by African actors and warn his interlocutors that appeals to a superpower presented a risk to Détente. The notes were not only paternalistic but also decidedly one-sided. Although the French and Belgian interventions in Shaba were briefly mentioned, Aubert's hint at the neocolonial designs of external powers and his wish that African states might preserve the biggest possible marge de manoeuvre in international affairs were clearly directed against the USSR. ${ }^{56}$ Aubert and his department applied different standards to foreign interventions on the African continent. Only those seemingly supported by the USSR were considered harmful and dangerous to regional and global stability. The mention of France, rather than the US, hints that Bern's concerns about growing Soviet influence in Africa and the seeming inability of the US to counter this were assuaged to some extent by the more active French role on the continent. FPD leaders seem to have approved of the French interventions in Zaire's Shaba province, as a sign that the French government was willing to assume responsibility for the defence of Western interests and to check what they considered aggressive Soviet behaviour.

In Switzerland, the planned Africa trip was controversial. First, Swiss business circles worried that the trip might draw negative attention to Switzerland's economic and financial relations with South Africa. This was particularly true in Nigeria, whose government was known for its outspoken position on white minority rule. Therefore, in December 1978, high-ranking representatives of Switzerland's leading export firms (Sulzer, ввс, Ciba-Geigy, and Nestlé), including prominent members of the SSAA, intervened twice in person to

Division, and selected Swiss embassies, "Die Möglichkeiten der westlichen Präsenz und die schweizerischen Interessen in Afrika”, 22.12.1978, SFA E2010-o1A\#19o/5\#197*. E2Oo1E-ol\#1988/16\#499*.

56 CJ, Sylvie Michl-Keller, speaking notes, "Voyage en Afrique occidentale du Chef du Département (14 au 30 janvier 1979). L'Afrique comme champ de confrontation des grandes puissances (URSS, USA, Chine)", 11.12.1978, SFA E2001E-o1\#1988/16\#499*. 
insist on maximum discretion regarding Apartheid. ${ }^{57}$ Second, the Trade Division and Federal Councillor Fritz Honegger of the FDEA insisted that greater priority should be attached to bilateral economic issues. ${ }^{58}$ Finally, large parts of the Swiss public and the press were very sceptical of the usefulness of 'travelling diplomacy', especially if they could not perceive a clear political or economic benefit that justified a state visit. Thanks to a misleading translation of an interview Aubert had granted to a Nigerian magazine in November 1978, some Swiss journals criticised the Federal Councillor for choosing relations with black-ruled Africa over those with South Africa. This was seen as contrary to Switzerland's policy of neutrality. ${ }^{59}$

During Aubert's trip to Western Africa, the controversy in Switzerland escalated. It focused on a short passage in a four-page communiqué published on 17 January 1979 on the occasion of the visit to Lagos. Aubert and the Nigerian Foreign Minister "condemned the violation of human rights all over the world and apartheid in particular." 60 Considered by many Swiss observers to be incompatible with Swiss neutrality because it singled out human rights abuses in South Africa, the Lagos statement was another bone of contention, alongside the ambition and cost of the programme, the information policy surrounding the visit, and Aubert's impulsive style of leadership. The more than 200

57 Georg Sulzer was the president of the SSAA, while Erwin Bielinski of ввС represented his firm in its committee. Ciba-Geigy and Nestlé also participated in this association: Gygax, La Suisse-South African Association, pp. 245-246, 291-292. Hansjakob Kaufmann, memorandum, 05.12.1978, SFA E2Oo1E-o1\#1991/17_Bd. 107, B.15.22.3; NF, memorandum, "Note sur l'entretien à Berne, chez le Chef du Département, avec MM. Georg sulze R, Sulzer Frères Sa, Erwin bielinski, bBC, WAldvogel, Ciba-Geigy, daniel, Nestlé, le 19 décembre 1978", 29.12.1978, p. 1, SFA E2001E-o1\#1991/17_Bd. 107, B.15.22.3.

58 Decree of the Federal Council, "Westafrika Reise des Departementschefs", 13.09.1978, SFA E2001E-o1\#1988/16\#499*; note from John Clerc, FPD, to Pierre Aubert, "Séance du Conseil federal du 10.1.1979. Voyage en Afrique occidentale”, o9.01.1979, SFA E2001E-o1\#1991/17_Bd. 107, B.15.22.3; Page, Le Nigeria et la Suisse, pp. 295-296.

59 On the subject of Swiss criticism of 'travelling diplomacy', see Kaufmann, Auslandreisen der Schweizer Bundesräte. Aubert's Africa trip is discussed on pp. $83^{-87}$, and, with a focus on the Nigerian stage, by Page, Le Nigeria et la Suisse, pp. 294-300.

6o Emphasis in original. Major-General H.E.O. Adefope, Nigerian Commissioner for External Affairs, and Pierre Aubert, "Joint communiqué on the official visit to Nigeria of the Honourable Swiss Foreign Minister, His Excellency, Mr. Pierre Aubert”, 17.01.1979, SFA E2001E-01\#1991/17_Bd. 106, B.15.22.3. The wording of this communiqué had been the subject of intense diplomatic exchange before the departure of the delegation: see the note from Hansjörg Renk, head of the FPD's Information and Press Service, "Nigéria. Communiqué commun", 12.01.1979, ibid., and the attached draft statements; No author, FPD, report, "Premier bilan du voyage du Chef du Département politique au Nigéria, au Cameroun, en Haute-Volta, en Côte d'Ivoire et au Sénégal (14 au 28 janvier 1979)", 30.01.1979, p. 5, SFA E2OO1E-o1\#1991/17_Bd. 106, B.15.22.3. 
editorials in Swiss journals that focused on the trip to Western Africa were also an expression of a certain unease about the active Swiss foreign policy propagated by Aubert. ${ }^{61}$

Assessments of Aubert's Western Africa trip varied greatly. Despite, and probably also because of, widespread criticism, the FPD insisted that the voyage had been largely successful. The department's first, internal report after the delegation's return maintained that the talks on economic issues had exceeded expectations. The visit had succeeded in fostering goodwill towards Switzerland and a deeper understanding of Switzerland's neutral status, which had a "not insignificant prophylactic value" for the protection of Swiss economic interests in Southern Africa. FPD leaders were also reassured that their interlocutors seemed well aware of the risk of further Soviet-Cuban interference in African affairs. ${ }^{62}$ Nevertheless, Aubert's Western Africa trip raised more profound questions about public acceptance of a dynamic Swiss foreign policy. On his return, the Federal Councillor had to justify his policy to the members of the parliamentary Foreign Policy Committees and to representatives of the Swiss export industry. The trip even triggered an important foreign policy debate in the Swiss parliament in March $1979 .{ }^{63}$

While domestic reactions to Aubert's visit reveal a deep-seated scepticism of Switzerland's active foreign policy, many external observers welcomed the trip as an expression of the country's willingness to play a more dynamic role in international affairs. In Africa, Aubert's visit generated positive headlines. ${ }^{64}$ The governments of the US, France, and the UK welcomed a more active Swiss foreign policy on the African continent. Even before Aubert's trip, the British

61 Mentioned in Hansjörg Renk, FM, Serge Salvi, DPA, press review, "Reise des Departementsvorstehers nach Westafrika" 14.02.1979, SFA E2001E-01\#1991/17_Bd. 107, B.15.22.3.

62 No author, FPD, report, "Premier bilan du voyage du Chef du Département politique au Nigéria, au Cameroun, en Haute-Volta, en Côte d'Ivoire et au Sénégal (14 au 28 janvier 1979)", 30.01.1979, citation p. 3, SFA E2001E-01\#1991/17_Bd. 106, B.15.22.3; see also the attached appendix no 1 by Jürg Andreas Iselin, "Erörterung politischer Fragen mit den Staatspräsidenten oder Aussenministern Nigerias, Kameruns, Obervoltas, der Elfenbeinküste und Senegals", 30.01.1979, p. 4.

63 See the minutes of the meeting of the National Council's Foreign Policy Committee on 5 February 1979, no date, SFA 1050.12\#1995/511\#23*; minutes of the meeting of the Council of States' Foreign Policy Committee on 6 Febuary 1979, no date, SFA 1050.12\#1995/512\#13*; Amtliches Bulletin der Bundesverfassung 1979, Frühlingssession Nationalrat, 14.03.1979, pp. 203-248; Amtliches Bulletin der Bundesverfassung 1979, Frühlingssession Ständerat, 21.03.1979, pp. 137-154; Rudolf Emil Stauch, memorandum of conversation, 19.03.1979, E20o1E-o1\#1991/17_Bd. 106, B.15.22.3; Fischer, Die Grenzen der Neutralität, pp. 274-276.

64 See Hansjörg Renk, FM, Serge Salvi, press review, "Reise des Departementsvorstehers nach Westafrika" 14.02.1979, pp. 11-12, SFA E2001E-o1\#1991/17_Bd. 107, B.15.22.3. 
ambassador in Bern was convinced that it would be to the Western world's advantage if Aubert were able to develop a foreign policy more attuned to Third World interests, despite the hesitancy of the Swiss population. ${ }^{65}$ Convinced "that Switzerland, too, could contribute to the 'depolarisation' of Africa", as Alfred Rüegg of the DPA put it in a memorandum in February 1979, the French government encouraged Switzerland's opening up towards African states. ${ }^{66}$ The US embassy in Bern advised the State Department in early February 1979 to facilitate Aubert's first official visit to the US, scheduled for May 1979, as much as possible. It was argued that the head of the FPD was in need of a political success in order to continue his active foreign policy: "If his US visit is not successfful [sic], there will be much 'schadenfreude' in the hearts of Swiss 'isolationists'. This would be detrimental to our own objectives of greater Swiss participation, [in] bilateral cooperation, and in solution of pol[itical]/ mil[itary] problems." ${ }^{67}$

Nevertheless, the novelty of Aubert's January 1979 trip should not distract from the fact that there was little fundamental change in Swiss policy towards Africa. The trip was an opportunity for dialogue and a show of respect. However, much as during the April 1972 OAU visit to Bern, the political gesture concealed the fact that, with regard to specific economic matters, there was no will to change. Following the Soviet-Cuban intervention in the Ogaden War, FPD leaders adopted a slightly more active policy on Africa. Switzerland's role during this conflict was largely passive. As there were few Swiss economic interests and citizens in the Horn of Africa, Bern's view of developments in this region was shaped by broader considerations - mainly the perceived threat of growing Soviet influence that was fuelled by the extensive military intervention. Presuming that the USSR's main objective on the continent was to drive a wedge between Western states and their economic interests in Africa, which potentially endangered Switzerland's own investments on the continent, Swiss foreign policymakers considered ways of participating in efforts to keep African states tied to the West. Concluding that African alliances with the Soviet Union were not founded on deep-rooted ideological convictions and that the

65 Alan K. Rothnie, British ambassador in Switzerland, report, "Swiss Foreign Policy (or Graber Plus)", 01.11.1978, p. 5, TNA FCO 33/3802.

66 Alfred Rüegg, memorandum, "Sowietische [sic] Einflussnahme in Afrika", 16.02.1979, SFA E2001E-o1\#1991/17_Bd. 111, B.15.22.4. See also the French embassy's report on Aubert's African trip: Letter from Claude Lebel, French ambassador in Switzerland, to Jean-François Poncet, French foreign minister, "Des résultats et des incidences du voyage de M. Aubert en Afrique", 07.02.1979, CAD 1929INVA4683.

67 Telegram from [?] Crowley, US embassy in Switzerland, to the Secretary of State, O2.02.1979, NARA, RG 59, AAD, CFPF, Electronic Telegrams 1979, 1979BERNoo658. 
West was a more attractive partner for economic cooperation, they argued that stronger political, economic, and development cooperation relations would reduce Soviet influence in Africa. Although the Swiss authorities realised, in late 1978, that their economic and financial relations with South Africa and Rhodesia represented the biggest threat to their interests on the African continent, they did not envisage taking any steps to limit them.

The controversy generated by Aubert's African visit, and especially by his Lagos statement on Apartheid, shows that even limited steps to strengthen the ties between Switzerland and Africa were a hard sell in Switzerland. The trip, seen as an expression of Aubert's attempts to render Swiss foreign policy more dynamic, revealed great resistance to an active Swiss foreign policy, in both parliament and public opinion. Many politicians, economic leaders, and a significant conservative segment of the Swiss public considered his limited openness to the Third World incompatible with a foreign policy based on neutrality. While influential voices in Switzerland demanded, in early 1979, that the country's economic and financial interests in South Africa be protected, the danger of Soviet influence in Africa was side-lined. When the Ogaden War was not followed by further Soviet-Cuban interventions, fear of a domino effect in Africa abated. This explains why, even though the Swiss government realised that the main risks to Swiss interests on the continent-on an economic, financial, and human level—were either located in Southern Africa or linked to Switzerland's policy in this region, the situation did not appear urgent enough to warrant fundamental change. Swiss foreign policymakers hid behind a rhetoric that insisted on the limited means of a small state to bring about change in Africa. They thereby concealed the fact that, given Switzerland's important economic and financial role in South Africa, its government certainly had some leverage. 